\title{
Detection of SHV $\beta$-lactamases in Gram-negative bacilli using fluorescein-labeled antibodies
}

\author{
Andrea M Hujer ${ }^{1}$, Karen S Keslar ${ }^{1}$, Nicole J Dietenberger ${ }^{1}$, \\ Christopher R Bethel ${ }^{1}$, Andrea Endimiani ${ }^{* 1,2}$ and Robert A Bonomo*1,3,4,5
}

\begin{abstract}
Address: ${ }^{1}$ Research Service, Louis Stokes Cleveland Department of Veterans Affairs Medical Center, Cleveland, OH, USA, ${ }^{2}$ Department of Medicine Section of Infectious Diseases, Case School of Medicine, Cleveland, OH, USA, ${ }^{3}$ Department of Pharmacology, Case School of Medicine, Cleveland, OH, USA, ${ }^{4}$ Department of Molecular Biology, Case School of Medicine, Cleveland, OH, USA and ${ }^{5}$ Department of Microbiology, Case School of Medicine, Cleveland, OH, USA

Email: Andrea M Hujer - ammh20@yahoo.com; Karen S Keslar - kes4fr@sbcglobal.net; Nicole J Dietenberger - njp232002@yahoo.com; Christopher R Bethel - crbeth1@yahoo.com; Andrea Endimiani* - aendimiani@gmail.com; Robert A Bonomo* - robert.bonomo@va.gov

* Corresponding authors
\end{abstract}

Published: 2 March 2009

BMC Microbiology 2009, 9:46 doi:10.1/86/1471-2180-9-46
Received: 19 September 2008

Accepted: 2 March 2009

This article is available from: http://www.biomedcentral.com/I47I-2/80/9/46

(C) 2009 Hujer et al; licensee BioMed Central Ltd.

This is an Open Access article distributed under the terms of the Creative Commons Attribution License (http://creativecommons.org/licenses/by/2.0), which permits unrestricted use, distribution, and reproduction in any medium, provided the original work is properly cited.

\begin{abstract}
Background: $\beta$-lactam resistance in Gram-negative bacteria is a significant clinical problem in the community, long-term care facilities, and hospitals. In these organisms, $\beta$-lactam resistance most commonly results from the production of $\beta$-lactamases. In Gram-negative bacilli, TEM-, SHV-, and CTX-M-type $\beta$-lactamases predominate. Therefore, new and accurate detection methods for these $\beta$-lactamase producing isolates are needed.
\end{abstract}

Results: $E$. coli DHIOB cells producing SHV-I $\beta$-lactamase and a clinical isolate of $K$. pneumoniae producing SHV-5 $\beta$-lactamase were rendered membrane permeable, fixed and adhered to poly-Llysine coated slides, and stained with purified polyclonal anti-SHV antibodies that were fluorescein labeled. E. coli DHIOB cells without a bla $a_{\mathrm{SHV}}$ gene were used as a negative control. The procedure generated a fluorescence signal from those slides containing cells expressing SHV $\beta$-lactamase that was sufficient for direct imaging.

Conclusion: We developed a rapid and accurate method of visualizing the SHV family of enzymes in clinical samples containing Gram-negative bacilli using a fluorescein-labeled polyclonal antibody.

\section{Background}

Resistance to $\beta$-lactam antibiotics in Gram-negative bacteria is a significant clinical problem in the community, long-term care, and hospital settings [1-3]. In the common Gram-negative bacteria that are responsible for most clinical infections, $\beta$-lactam resistance results from production of penicillinases (predominantly the $\beta$-lactamases designated TEM-1 and SHV-1), cephalosporinases (e.g., extended-spectrum $\beta$-lactamases, ESBL, of TEM-, SHV- and CTX-M-types), and the chromosomally or plas- mid encoded AmpC enzymes [1]. Hence, an aggressive search for novel therapeutic agents and rapid, accurate detection methods is necessary.

Polymerase chain reaction (PCR) based techniques (such as multiplex PCR, real time PCR, DNA microarrays) and DNA-DNA hybridization have been used with success to detect bla genes in Gram-negative bacilli [4-10]. Most recently, fluorescence in situ hybridization (FISH) using rRNA oligonucleotides has also been employed to detect 
$\beta$-lactamase genes $[11,12]$. Unfortunately, not all clinical microbiology laboratories can perform the above molecular techniques. Even if available, these methodologies are not routinely used to study clinical samples because they are expensive and time consuming. We would also emphasize that a PCR amplification product indicates the presence of the gene only and does not always indicate protein production.

In a previous study, our laboratory raised and characterized polyclonal antibodies against the SHV- $1 \beta$-lactamase $[13,14]$. Immunogenic epitope mapping of the SHV $\beta$ lactamase was reported. The polyclonal antibodies detected as little as $1 \mathrm{ng}$ of $\beta$-lactamase by immunoblotting and pg quantities by enzyme-linked immunosorbent assay (ELISA). Notably, cross reaction with other class A $\beta$ lactamases (i.e., TEM- and CMY-2-like enzymes) was not observed [13,14].

In this report, we extend our investigations and describe a method using fluorescein-labeled polyclonal antibodies (FLABs) to visualize the SHV-type $\beta$-lactamases expressed in a laboratory strain of Escherichia coli and in a clinical isolate of Klebsiella pneumoniae. With this technique, we have developed a new method by which we could rapidly detect SHV-type $\beta$-lactamases in clinical samples using FLABs and fluorescence microscopy.

\section{Methods}

The SHV-1 $\beta$-lactamase gene was sub-cloned into the pBC SK(-) vector (Stratagene, LaJolla, CA) from a clinical strain of K. pneumoniae (15571), and transformed into E. coli DH10B cells (Invitrogen, Carlsbad, CA) [15]. The K. pneumoniae clinical isolate possessed the SHV-5 ESBL and was obtained from a previous study [16]. E. coli DH10B without the $b l a_{\mathrm{SHV}-1}$ gene served as a negative control.

The procedures used to isolate, express and purify the SHV-1 $\beta$-lactamase and to produce the anti-SHV $\beta$-lactamase antibodies have been previously detailed [13]. Purified anti-SHV antibodies were fluorescein-labeled with the EZ-Label ${ }^{\mathrm{TM}}$ fluorescent labeling kit (Pierce, Rockford, IL), according to the instructions of the manufacturer. In brief, $1 \mathrm{mg}$ of polyclonal anti-SHV antibodies in $1 \mathrm{ml}$ phosphate buffered saline (PBS, $2 \mathrm{mM}$ monobasic sodium phosphate, $8 \mathrm{mM}$ dibasic sodium phosphate, 154 mM sodium chloride, $\mathrm{pH} 7.4$ ) was mixed with $7.6 \mu \mathrm{l}$ of a $10 \mathrm{mg} / \mathrm{ml}$ solution of NHS-fluorescein in N, N-dimethylformamide for $1 \mathrm{hr}$ at room temperature. A desalting column was then used to separate unbound fluorescein from labeled antibodies. Labeled antibodies exiting the column were monitored by measuring the absorbance of the samples at $280 \mathrm{~nm}$. Then, the labeled antibodies were filtersterilized, protein concentration determined, and stored at $4^{\circ} \mathrm{C}$.
E. coli $\mathrm{DH} 10 \mathrm{~B}$ with and without the $b l a_{\mathrm{SHV}-1}$ gene in the pBC SK(-) phagemid vector and the clinical isolate of $K$. pneumoniae possessing the SHV-5 $\beta$-lactamase were prepared for staining and visualization by fluorescence microscopy on a Zeiss Axiovert 200 inverted scope. Stationary phase cells were grown to $37^{\circ} \mathrm{C}$ in Luria Bertani broth supplemented with either $20 \mu \mathrm{g} / \mathrm{ml}$ of chloramphenicol (Sigma, St. Louis, MO) or $50 \mu \mathrm{g} / \mathrm{ml}$ ampicillin (Sigma), for E. coli DH10B harboring the bla $a_{\mathrm{SHV}-1}$ gene or the clinical isolate of K. pneumoniae, respectively. Antibiotics were not used in the case of E. coli DH10B cells alone. Overnight cultures were diluted to an $\mathrm{OD}_{600} \mathrm{~nm}$ of 0.5 and $500 \mu \mathrm{l}$ of cells were spun down and re-suspended in $500 \mu \mathrm{l}$ of $50 \mathrm{mM}$ Tris $\mathrm{HCl}, \mathrm{pH}$ 7.4. Lysozyme was added to a final concentration of $1 \mathrm{mg} / \mathrm{ml}$ for $5 \mathrm{~min}$, followed by addition of $1 \mathrm{mM}$ EDTA for $5 \mathrm{~min}$. Cells were then pelleted (5000 $\mathrm{g} \times 5 \mathrm{~min}$ ), washed twice with PBS, and re-suspended in $500 \mu \mathrm{l}$ of PBS. Cells were fixed with the addition of $100 \mu \mathrm{l}$ of fixation buffer containing $200 \mathrm{mM}$ dibasic sodium phosphate, $0.3 \%$ glutaraldehyde, and $2 \%$ formaldehyde (Sigma). Cells were incubated for $10 \mathrm{~min}$ at room temperature and then for $45 \mathrm{~min}$ on ice, washed once with PBS, and re-suspended in $250 \mu \mathrm{l}$ PBS. Ten $\mu \mathrm{l}$ of this suspension was placed on a poly-L-lysine coated slide (Sigma), and after $1 \mathrm{~min}$ the liquid was aspirated off. The adhered cells were gently washed once with $50 \mu$ of PBS and then the specimen was allowed to dry completely.

The fixation procedure was followed by re-hydration and staining. Each cell-adhered area was re-hydrated by adding $100 \mu \mathrm{l}$ of PBS for $4 \mathrm{~min}$ followed by aspiration. Each area was then blocked with $2 \%$ bovine serum albumin (BSA), in PBS for $15 \mathrm{~min}$ at room temperature in a humidity chamber, followed by aspiration. A $5 \mu \mathrm{g} / \mathrm{ml}$ solution of FLABs in 2\% BSA in PBS was then added and allowed to incubate for $2 \mathrm{hrs}$ in the humidity chamber. The cells were then washed 10 times with PBS, the excess liquid was aspirated off, and 2-3 drops of Gelmount was added followed by the addition of a coverslip. The procedure aimed for a fluorescence signal sufficient for imaging directly. The Zeiss Axiovert 200 inverted scope was equipped with an Axiocam digital microscope camera to capture immunofluorescence images.

\section{Results and discussion}

Figure 1 demonstrates the immunofluorescence images obtained using the fluorescence microscope at $1000 \times$ total magnification. Figure $1 \mathrm{a}$ and $1 \mathrm{~b}$ show E. coli DH10B cells devoid of SHV $\beta$-lactamase stained with anti-SHV FLABs. In Figure $1 \mathrm{c}$ and $1 \mathrm{~d}$ we reveal the ability of antiSHV FLABs to detect periplasmic SHV $\beta$-lactamases in a clinical K. pneumoniae isolate expressing the SHV-5 $\beta$ lactamase. Figure $1 \mathrm{e}$ and $1 \mathrm{f}$ demonstrate the visualization of SHV-1 $\beta$-lactamase in a laboratory strain of E. coli encoding and expressing SHV-1. In both instances, the 

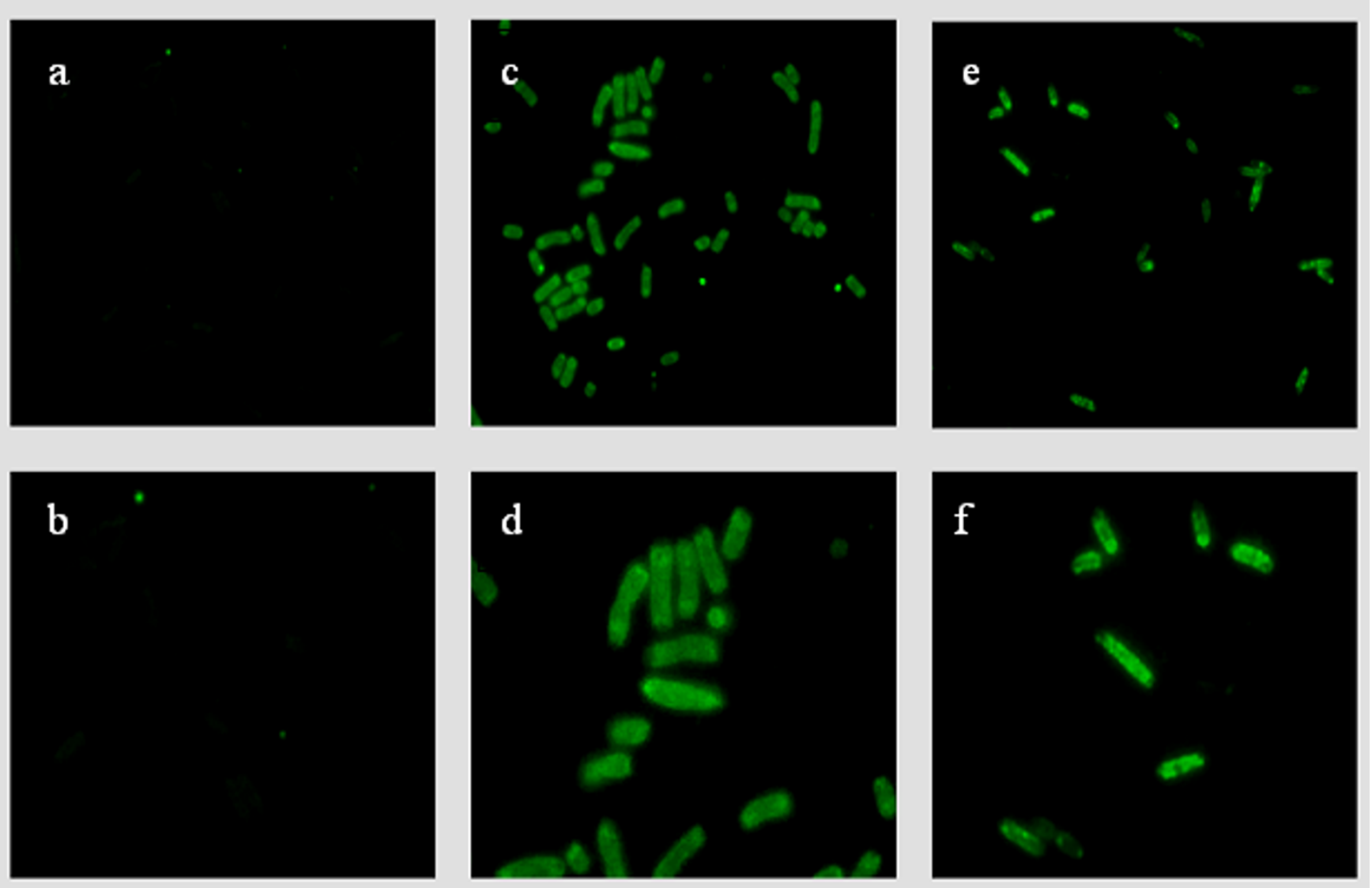

Figure I

$a$ and b: $E$. coli DHIOB cells devoid of SHV $\beta$-lactamase stained with anti-SHV FLABs. c and d: detection of periplasmic SHV $\beta$-lactamase in a $K$. pneumoniae clinical isolate possessing the SHV-5 $\beta$-lactamase. e and f: visualization of SHV-I $\beta$ lactamase in a laboratory strain of $E$. coli expressing SHV-I. Microscopic magnification is I000x. Figure Ib, Id, and If are enlarged images.

FLABs readily detected the SHV $\beta$-lactamases. It is also noteworthy that this imaging technique reveals the morphology of the isolates with great definition.

Although PCR amplification remains the "gold standard" for the identification of $b l a_{\mathrm{SHV}}$ and other bla genes, FLABs may prove to be a rapid and easy "bench top" method. Our technique could be developed and used to rapidly test clinically important samples (e.g., blood and sputum) in a microbiology laboratory where the use of molecular methods (e.g., PCR/sequencing) is less feasible. By extension, interest will also be keen to assess the presence, distribution and regulation of $\beta$-lactamase expression in biofilms in device-associated infections.

When employing the FLABs method for $\beta$-lactamase detection, three important caveats should be kept in mind. Firstly, FLABs cannot distinguish between narrowspectrum (e.g., SHV-1), broad-spectrum (e.g., SHV-11), and ESBLs (e.g., SHV-5 and SHV-12). Nevertheless, for Gram-negative organisms that do not express chromosomal SHV-type $\beta$-lactamases (e.g., E. coli, Proteus spp., Enterobacter spp.), evidence of SHV-type production is often associated with ESBLs. In this case, rapid identification of SHV enzymes could temper the use of cephalosporins and suggest an alternative antibiotic (e.g., carbapenems) in the critically ill patient with a serious infection. Secondly, low level $\beta$-lactamase expression due to either promoter mutations or gene copy number may affect the ability of FLABs to detect these enzymes. However, it has been shown that the limit of detection/sensitivity in ELISA experiments is at pg levels [13]. Thirdly, FLABs may cross react and detect the homologous LENtype enzyme (possessed by some K. pneumoniae). In this study we were not able to rule out the possibility of crossreaction between our FLABs and the LEN-type enzymes because we do not possess a highly-purified LEN-type $\beta$ lactamase and/or an isolate producing the $b l a_{\mathrm{LEN}}$ gene 
alone. Based on a comparison of amino acids sequences of SHV-1 and LEN-1 enzymes a homology of 90\% was observed. We compared the immunogenic epitopes of SHV-1 to the amino acid sequence of LEN-1 [14]: the most higly recognized epitope showed $100 \%$ identity with the amino acid sequence of SHV-1 (data not shown). Therefore, it is possible that the LEN-type $\beta$-lactamase could be detected by our FLABs.

\section{Conclusion}

We developed a rapid and accurate method of visualizing the SHV family of enzymes in clinical samples containing Gram-negative bacilli using fluorescein-labeled polyclonal antibodies. It has not escaped our attention that this approach can also be applied to other $\beta$-lactamase types and for different Gram-negative species. The application of this methodology for clinical samples could help to rapidly identify SHV production and promptly implement a more appropriate antibiotic therapy improving clinical outcome (e.g., length of hospital stay and mortality) of patients with serious infections due to different Gram-negative bacilli. The development of specific monoclonal antibodies would ensure more widespread application and supply. Further studies are planned to determine the ability of this method to detect SHV $\beta$-lactamase in a wide range of clinical isolates and to assess the localization of $\beta$-lactamases within the cell [17].

\section{Abbreviations}

BSA: bovine serum albumin; ELISA: enzyme-linked immunosorbent assay; FISH: fluorescence in situ hybridization; FLAB: fluorescein-labeled polyclonal antibody; PBS: phosphate buffered saline; PCR: polymerase chain reaction; SHV: sulfhydryl reagent variable [18]; TEM: $\beta$ lactamase named after the patient Temoneira providing the first sample [18]; ESBL: extended-spectrum $\beta$-lactamase.

\section{Authors' contributions}

$\mathrm{AMH}, \mathrm{KSK}, \mathrm{NJD}$, and CRB involved in study design and execution of experiments. $\mathrm{AMH}, \mathrm{AE}$, and $\mathrm{RAB}$ study design and manuscript preparation. All authors read and approved the final manuscript.

\section{Acknowledgements}

This work was supported by grants from the Veterans Affairs Medical Center Merit Review (RAB), the National Institutes of Health (NIH ROIAl0635I7 to RAB), and the Geriatric Research, Education and Clinical Care VISN 10 (RAB).

\section{References}

I. Paterson DL, Bonomo RA: Extended-spectrum beta-lactamases: a clinical update. Clin Microbiol Rev 2005, 18(4):657-686.

2. Rodriguez-Bano J, Navarro MD: Extended-spectrum beta-lactamases in ambulatory care: a clinical perspective. Clin Microbiol Infect 2008, I4(SuppI I): 104-I I0.
3. Nicolas-Chanoine MH, Jarlier V: Extended-spectrum beta-lactamases in long-term-care facilities. Clin Microbiol Infect 2008, I4(Suppl I): III-II6.

4. Chaves J, Ladona MG, Segura C, Coira A, Reig R, Ampurdanes C: SHV-I beta-lactamase is mainly a chromosomally encoded species-specific enzyme in Klebsiella pneumoniae. Antimicrob Agents Chemother 200I, 45( I 0):2856-286I.

5. Colom K, Perez J, Alonso R, Fernandez-Aranguiz A, Larino E, Cisterna R: Simple and reliable multiplex PCR assay for detection of blaTEM, bla(SHV) and blaOXA-I genes in Enterobacteriaceae. FEMS Microbiol Lett 2003, 223(2): 147-15I.

6. Grimm V, Ezaki S, Susa M, Knabbe C, Schmid RD, Bachmann TT: Use of DNA microarrays for rapid genotyping of TEM beta-lactamases that confer resistance. I Clin Microbiol 2004, 42(8):3766-3774.

7. Perez-Perez FJ, Hanson ND: Detection of plasmid-mediated AmpC beta-lactamase genes in clinical isolates by using multiplex PCR. J Clin Microbiol 2002, 40(6):2I 53-2I62.

8. Randegger CC, Hachler H: Real-time PCR and melting curve analysis for reliable and rapid detection of SHV extendedspectrum beta-lactamases. Antimicrob Agents Chemother 200I, 45(6): $1730-1736$.

9. Volkmann H, Schwartz T, Bischoff P, Kirchen S, Obst U: Detection of clinically relevant antibiotic-resistance genes in municipal wastewater using real-time PCR (TaqMan). J Microbiol Methods 2004, 56(2):277-286.

10. Weldhagen GF: Sequence-selective recognition of extendedspectrum beta-lactamase GES-2 by a competitive, peptide nucleic acid-based multiplex PCR assay. Antimicrob Agents Chemother 2004, 48(9):3402-3406.

II. Palasubramaniam S, Muniandy S, Navaratnam P: Rapid detection of ESBL-producing Klebsiella pneumoniae in blood cultures by fluorescent in-situ hybridization. J Microbiol Methods 2008, 72(I): 107-109.

12. Zwirglmaier K, Ludwig W, Schleifer KH: Recognition of individual genes in a single bacterial cell by fluorescence in situ hybridization - RING-FISH. Mol Microbiol 2004, 5 I ( I):89-96.

13. Hujer AM, Page MG, Helfand MS, Yeiser B, Bonomo RA: Development of a sensitive and specific enzyme-linked immunosorbent assay for detecting and quantifying CMY-2 and SHV beta-lactamases. J Clin Microbiol 2002, 40(6): 1947-1957.

14. Hujer AM, Bethel CR, Bonomo RA: Antibody mapping of the linear epitopes of CMY-2 and SHV-I beta-lactamases. Antimicrob Agents Chemother 2004, 48(10):3980-3988.

15. Rice LB, Carias LL, Hujer AM, Bonafede M, Hutton R, Hoyen C, Bonomo RA: High-level expression of chromosomally encoded SHV-I beta-lactamase and an outer membrane protein change confer resistance to ceftazidime and piperacillin-tazobactam in a clinical isolate of Klebsiella pneumoniae. Antimicrob Agents Chemother 2000, 44(2):362-367.

16. Paterson DL, Hujer KM, Hujer AM, Yeiser B, Bonomo MD, Rice LB, Bonomo RA: Extended-spectrum beta-lactamases in Klebsiella pneumoniae bloodstream isolates from seven countries: dominance and widespread prevalence of SHV- and CTX-M-type beta-lactamases. Antimicrob Agents Chemother 2003, 47(II):3554-3560.

17. Wagner B, Fattorini L, Wagner M, Jin SH, Stracke R, Amicosante G, Franceschini N, Orefici G: Antigenic properties and immunoelectron microscopic localization of Mycobacterium fortuitum beta-lactamase. Antimicrob Agents Chemother 1995, 39(3):739-745.

18. Jacoby GA: Beta-lactamase nomenclature. Antimicrob Agents Chemother 2006, 50(4): I I23-II 29. 